\title{
Pharmacological Investigation of Selected Medicinal Plants of Bangladesh
}

\author{
Abu Hasanat Md. Zulfiker ${ }^{1,2}$, Md Amdadul Hoque ${ }^{3}$, Tanzena Akter ${ }^{4}$, Aysha \\ Afroz $^{2}$ and Mohammad Abdul Motalib Momin ${ }^{5 *}$ \\ ${ }^{1}$ Division of Molecular and Gene Therapies, School of Medical Science and Griffith Health Institute, Griffith University, Gold \\ Coast Campus, QLD, 4222, Australia, '2Department of Pharmacy, School of Science \& Engineering, Southeast University, \\ Banani, Dhaka-1213, ${ }^{3}$ Department of Pharmacy, North South University, Bashundhara, Dhaka-1229, ${ }^{4}$ Department of \\ Pharmacy, East West University, Aftabnagar, Dhaka-1219, ${ }^{5}$ Department of Pharmacy, Jahangirnagar University, Savar, Dhaka- \\ 1342, Bangladesh
}

*For correspondence: Email: motalib_ju@yahoo.com; Tel: +8801718072824

Received: 24 February 2014

Revised accepted: 20 September 2014

\begin{abstract}
Purpose: To pharmacologically investigate the methanol and petroleum ether extracts of the plant leaves of Manilkara zapota (MZME and MZPE, respectively), Abroma augusta (AAME and AAPE, respectively) and Vitex negundo (VNME and VNPE, respectively).

Methods: Analgesic and anti-diarrheal activities were assessed by acetic acid-induced writhing and castor oil-induced diarrhea in mice, respectively, while CNS depressant activity was evaluated using hole-cross and open-field method by observing the decrease in exploratory behavior and spontaneous motor activity in mice, respectively.

Results: All the extracts exhibited good analgesic activity at a dose of $200 \mathrm{mg} / \mathrm{kg}$ with the following rank order of activity: MZME > MZPE > VNME > VNPE > AAME > AAPE. Analgesic activity was insignificant at $100 \mathrm{mg} / \mathrm{kg}$ dose except for VNPE (67.81\% inhibition). The extracts produced significant reduction in diarrheal episodes in mice at a dose of $400 \mathrm{mg} / \mathrm{kg}$ MZPE (highest protection: $80.3 \%, p<0.05$ ) and VNME (lowest protection: $38.6 \%, p<0.001$ ). The extracts demonstrated CNS depressant activity in a dose-dependent manner $(p<0.05$ compared to the standard except for AAME and AAPE which showed insignificant activity).

Conclusion: The results indicate that the traditional use of the investigated plants appears to be justified; however, further studies are required to unravel the underlying mechanisms of action.
\end{abstract}

Keywords: Manilkara zapota, Abroma augusta, Vitex negundo, Analgesic, Central nervous system depressant, Anti-diarrhoeal

\begin{abstract}
Tropical Journal of Pharmaceutical Research is indexed by Science Citation Index (SciSearch), Scopus, International Pharmaceutical Abstract, Chemical Abstracts, Embase, Index Copernicus, EBSCO, African Index Medicus, JournalSeek, Journal Citation Reports/Science Edition, Directory of Open Access Journals (DOAJ), African Journal Online, Bioline International, Open-J-Gate and Pharmacy Abstracts
\end{abstract}

\section{INTRODUCTION}

Among the south Asian countries, Bangladesh has a rich and prestigious heritage of herbal medicines. Out of 500 species of medicinal plants about 250 species are used for the preparation of traditional medicines in Bangladesh. But majority of these plants have not yet undergone chemical, pharmacological and toxicological studies to investigate their bioactive compounds [1].

Manilkara zapota $(L)$ is an evergreen, glabrous tree under the family Sapotaceae. It is cultivated throughout the Indian subcontinent. In Bangladesh the local name is Sofeda. The leaves of this plant are used to treat cough, cold, and diarrhoea [2]. Abroma augusta (L) is a plant 
under family of Sterculiaceae and Ulat kambal is the trade name of this plant. Leaves are used to treat uterine disorders, diabetes, rheumatic pain of joints, and headache with sinusitis [3]. Leaves and stem are demulcent and an infusion of fresh leaves and stem in cold water is very efficacious in gonorrhea [4]. Vitex negundo (L) is a plant under family of Verbenaceae which is locally known as nishinda in Bangladesh. The leaves and the roots of this plant are important as drugs. Anti-inflammatory and analgesic properties of mature fresh leaves have been reported [5].

In our laboratory we previously investigated the leaves of these plants for antioxidant \& antimicrobial potential which were collected from a different region of Bangladesh [6]. The present study was undertaken to further explore these plants as a part of our endeavor to look for medicinal properties in local floristic resources.

\section{EXPERIMENTAL}

\section{Collection and identification of plant material}

The investigated plants, namely, Manilkara zapota, Abroma augusta and Vitex negundo were collected from Magura, Bhola, Dhaka, Bangladesh in February 2011 and $\mathrm{Dr}$ MA Razzaque Shah, Tissue Culture Specialist, BRAC Plant Biotechnology Laboratory, Bangladesh authenticated the plants and their voucher specimens (nos. 35493, 35510 and 35401 respectively) were deposied in Bangladesh National Herbarium, Mirpur, Dhaka for future reference.

\section{Chemicals and drugs}

Tween-80 (as suspending agent), DMSO (as suspending \& solubilizing agent) were purchased from BDH Chemicals Ltd and Merck, Germany; Diazepam and Sterile normal saline solution (0.9 $\% \mathrm{NaCl}$ ) were collected from Incepta Pharmaceuticals Ltd., and Beximco Infusion Ltd. Bangladesh.

\section{Drying and pulverization}

The fresh leaves of the plants were first washed with water to remove adhering dirt and then cut into small pieces, dried in the laboratory for 7 days. After complete drying, the entire portions were pulverized into a coarse powder with the help of a grinding machine and were stored in an airtight container for further use. The powder was stored in an airtight container and kept in a cool, dark and dry place until analysis commenced.

\section{Cold extraction}

About $180 \mathrm{gm}$ of Manilkara zapota, $150 \mathrm{gm}$ of Abroma augusta Linn, $500 \mathrm{gm}$ of Vitex negundo Linn powdered materials were placed in separate glass containers and soaked in $700 \mathrm{ml}$ of $95 \%$ methanol. The container with its contents was sealed and kept for a period of 7 days accompanying occasional shaking and stirring. The whole mixture then underwent a coarse filtration by a piece of clean, white cotton material. Then it was filtered through Whatman filter paper (Bibby RE200, Sterilin Ltd., UK).

\section{Extraction with methanol}

The concentrated methanol extract was made slurry with water. The slurry was taken in a separating funnel and methanol $(50 \mathrm{ml})$ was added to the aqueous solution and the mass was shaken vigorously in a separating funnel. Then the funnel was allowed to stand for few minutes for the complete separation of the layers. The organic (lower layer) layer was collected. The process was repeated two times.

\section{Extraction with petroleum ether}

After methanol extraction, petroleum ether (70 $\mathrm{ml}$ ) was added to the methanolic aqueous solution and the mass was shaken vigorously in a separating funnel. Then the funnel was allowed to stand for few minutes for the complete separation of the layers. The organic (upper layer) layer was collected. The process was repeated two times.

The filtrate (methanol and petroleum ether extract) obtained was evaporated at $50^{\circ} \mathrm{C}$ under reduced pressure using vacuum pump rotary evaporator (STUART RF3022C, UK). It rendered a gummy concentrate of reddish black color. The extract was transferred to a closed container for further use and protection.

\section{Experimental animal}

Young Swiss-albino mice of either sex, aged 4 5 weeks, average weight 25 - $30 \mathrm{~g}$ were used for the experiment. The mice were purchased from the animal research branch of the International Centre for Diarrheal Disease and Research, Bangladesh (ICDDR, B). They were kept in standard environmental conditions $\left(24.0 \pm 0{ }^{\circ} \mathrm{C}\right.$ $55-65 \%$ relative humidity and $12 \mathrm{~h}$ light/12 h dark cycle) for one week for acclimation, and fed on ICDDR, B-formulated rodent food and water ad libitum. All protocols were approved by the institutional animal ethical committee (Southeast University Animal Ethics committee, Southeast 
University, Banani, Dhaka (approval ref no. SEU01) and followed international guidelines for handling of animals for the investigation of experimental pain [7].

\section{Evaluation of analgesic potential}

The analgesic activity of the extracts was evaluated using acetic acid induced writhing method in mice $[8,9]$. As a positive control, any standard NSAID drug, indomethacin was used. Thirty six experimental animals were randomly selected and divided into six groups denoted as group-I, group-II, group-III, group-IV, group-V and group-VI consisting of 6 mice in each group. Each group received a particular treatment i.e. control, standard and the dose of the extracts of the plant respectively. Prior to any treatment, each mouse was weighed properly and the dose of the test sample and control materials was adjusted accordingly. The plant extracts were administered orally in two different doses (100 and $200 \mathrm{mg} / \mathrm{kg}$ body weight) to Swiss albino mice after an overnight fast. Each mouse in all the groups was observed carefully to count the number of writhing.

\section{Evaluation of CNS depressant effect}

CNS depressant activity was evaluated using hole cross and open field method.

\section{Hole cross test}

The method was adopted as described by [10]. A steel partition was fixed in the middle of a cage having a size of $30 \times 20 \times 14 \mathrm{~cm}$. A hole of $3 \mathrm{~cm}$ diameter was made at a height of $7.5 \mathrm{~cm}$ in the centre of the cage. The number of passage of a mouse through the hole from one chamber to the other was counted for a period of $3 \mathrm{~min}$ at 0,30 , 60,90 and 120 min after oral administration of the crude extracts at doses of 250 and 500 $\mathrm{mg} / \mathrm{kg}$ body weight of mice.

\section{Open field test}

This experiment was carried out as described by [11]. The animals were divided into control and test groups containing 6 mice each. The test group received extract at the doses of 250 and $500 \mathrm{mg} / \mathrm{kg}$ body weight orally whereas the control group received vehicle (1\% Tween 80 in water). The floor of an open field of half square meter was divided into a series of squares, each alternatively colored black and white. The apparatus had a wall of $40 \mathrm{~cm}$ height. The number of squares visited by the animals was counted for $3 \mathrm{~min}$ at $0,30,60,90$ and $120 \mathrm{~min}$ after oral administration of the crude extracts at doses of 250 and $500 \mathrm{mg} / \mathrm{kg}$ body weight of mice.

\section{Evaluation of anti-diarrhoeal activity}

The anti-diarrheal activity was performed by the method developed by [12]. Animals were divided into six groups of six animals in each group. Group I received $1 \mathrm{ml}$ castor oil and served as control. Groups II received castor oil and standard drug, (Loperamide, $3 \mathrm{mg} / \mathrm{kg}$ ) and served as standard. Group V-VI received methanolic extracts (200 and $400 \quad \mathrm{mg} / \mathrm{kg}$ respectively). Diarrhea was induced in all the overnight fasted animals by administering $1 \mathrm{ml}$ of castor oil orally. The test extracts and the standard drug were administered one hour prior to the treatment of castor oil. Each mouse was housed separately and observed for diarrheal episode, for a period of $3 \mathrm{~h}$. During that period, number and weight of diarrheal feces were taken and noted at every half an hour. The mean diarrheal episodes and percent protection was calculated. The anti-diarrheal activity was determined in terms of percentage protection. The data of stool weight were expressed as mean \pm SEM.

\section{Statistical analysis}

Data of all experiments were reported as mean \pm SEM. Statistical significance testing of the values obtained were performed by one-way analysis of variance (ANOVA) and the group means were evaluated using Dunnett's multiple comparisons for analgesic screening tests and Tukey's multiple comparisons for neuropharmacological tests using SPSS program (SPSS 16.0, USA). The results were further analyzed using Student's t-test for castor oil-induced diarrhoea. In all cases, the data obtained were compared with the vehicle control group. Differences were considered statistically significant when $p<0.05$.

\section{RESULTS}

\section{Analgesic activity}

Table 1 shows the result for the writhing tests for methanol and pet ether extracts of the three plants. Compared with the standard, the effects of analgesic activity of petroleum ether and methanolic extracts at the dose of $100 \mathrm{mg} / \mathrm{kg}$ showed insignificant writhing in mice except VNPE and VNME. At the dose of $200 \mathrm{mg} / \mathrm{kg}$ all the extracts showed significant writhing and sequence of percent inhibition is MZME > MZPE $>$ VNME $>$ VNPE $>$ AAPE $>$ AAME. Among the 
extracts, the MZME was the most potent and AAME was least potent.

\section{CNS depressant activity}

\section{Hole cross}

Both petroleum ether and methanolic extracts of Manilkara zapota and Vitex negundo showed a noticeable decrease of exploratory behavior in the test animals from its initial value at 0 to 120 min (Table 2). The results were dose-dependent and significant at $p<0.05$ level, At $30 \mathrm{~min}$, VNME $(500 \mathrm{mg} / \mathrm{kg})$ and VNPE $(250 \mathrm{mg} / \mathrm{kg})$ are significant compared to standard. At $60 \mathrm{~min}$, all test samples are significant compared to standard. At 90 minutes, both MZME and MZPE are significant compared to control but not standard at the dose of 250 and $500 \mathrm{mg} / \mathrm{kg}$. In case of Abroma augusta, both extracts insignificantly decreased the locomotor activity.

\section{Open field}

The petroleum ether and methanol extracts of Manilkara zapota and Vitex negundo at various dose levels both decreased locomotor and exploratory activity of experimental animal. In Manilkara zapota, at $0 \mathrm{~min}$ pet ether $250 \mathrm{mg} / \mathrm{kg}$ is significant $(p<0.05)$ compared to standard. Otherwise all data are insignificant compared to control and standard (Table 3). In case of Abroma augusta, the result indicates that the both extracts insignificantly decreased the locomotor activity.

Table 1: Effect of methanol and petroleum ether extracts of Manilkara zapota, Abroma augusta, and Vitex negundo on acetic acid induced writhing in mice

\begin{tabular}{|c|c|c|c|}
\hline Treatment & Dose (mg/ kg, p.o) & No. of writhing & $\%$ Inhibition \\
\hline Control & $0.5 \mathrm{ml} / \mathrm{mouse}$ & $39.25 \pm 8.02$ & 0 \\
\hline Standard control & $10 \mathrm{ml} / \mathrm{kg}$ & $18.50 \pm 7.64$ & 52.87 \\
\hline \multirow[t]{2}{*}{ MZPE } & 100 & $15.75 \pm 9.98$ & 59.87 \\
\hline & 200 & $2.25 \pm 0.87$ & 94.27 \\
\hline \multirow[t]{2}{*}{ MZME } & 100 & $25.25 \pm 9.11$ & 35.67 \\
\hline & 200 & $1.25 \pm 1.09^{* \pi}$ & 96.82 \\
\hline \multirow[t]{2}{*}{ AAPE } & 100 & $14.50 \pm 4.01$ & 17.14 \\
\hline & 200 & $6.75 \pm 3.10^{*}$ & 61.43 \\
\hline \multirow[t]{2}{*}{ AAME } & 100 & $12.25 \pm 3.81$ & 30.00 \\
\hline & 200 & $7.12 \pm 3.32^{*}$ & 59.30 \\
\hline \multirow[t]{2}{*}{ VNPE } & 100 & $4.62 \pm 1.85^{*}$ & 67.81 \\
\hline & 200 & $5.87 \pm 2.50^{*}$ & 74.66 \\
\hline \multirow[t]{2}{*}{ VNME } & 100 & $3.00 \pm 2.05^{* *}$ & 81.16 \\
\hline & 200 & $3.25 \pm 0.99 * *$ & 82.62 \\
\hline
\end{tabular}

Values are presented as mean $\pm \operatorname{SEM}(n=6) ;{ }^{*} p<0.05,{ }^{* *} p<0.001$ compared to control (Dunnett's test)

Table 2: Effects of petroleum ether and methanolic extracts of Manilkara zapota, Abroma augusta, and Vitex negundo in mice on hole cross test

\begin{tabular}{|c|c|c|c|c|c|c|}
\hline \multirow[t]{2}{*}{ Groups } & \multirow{2}{*}{$\begin{array}{c}\text { Dose } \\
\text { (mg/kg, p.o) }\end{array}$} & \multicolumn{5}{|c|}{ Mean movements on open field before and after drug administration } \\
\hline & & $0 \mathrm{~min}$ & $30 \mathrm{~min}$ & $60 \mathrm{~min}$ & $90 \mathrm{~min}$ & $120 \mathrm{~min}$ \\
\hline Control & $\begin{array}{l}1 \% \text { Tween } \\
80 \text { in water }\end{array}$ & $7.25 \pm 2.08$ & $5.00 \pm 1.25$ & $2.75 \pm 1.85$ & $2.75 \pm 1.09$ & $1.50 \pm 1.00$ \\
\hline $\begin{array}{l}\text { Diazepam } \\
\text { MZPE }\end{array}$ & $\begin{array}{c}1 \\
250\end{array}$ & $\begin{array}{l}9.75 \pm 3.18 \\
3.75 \pm 2.89\end{array}$ & $\begin{array}{l}7.75 \pm 2.23 \\
0.75 \pm 0.55^{*}\end{array}$ & $\begin{array}{l}6.50 \pm 2.77 \\
0.50 \pm 0.33\end{array}$ & $\begin{array}{l}3.25 \pm 0.87 \\
0.25 \pm 0.29^{*}\end{array}$ & $\begin{array}{c}2.00 \pm 1.33 \\
0\end{array}$ \\
\hline & 500 & $7.50 \pm 5.22$ & $2.75 \pm 2.02$ & $0.75 \pm 0.55$ & $0^{*}$ & 0 \\
\hline MZME & $\begin{array}{l}250 \\
500\end{array}$ & $\begin{array}{l}4.00 \pm 2.16 \\
5.25 \pm 4.09\end{array}$ & $\begin{array}{r}4.00 \pm 2.11 \\
1.50 \pm 1.00\end{array}$ & $\begin{array}{c}0^{*} \\
1.25 \pm 1.09\end{array}$ & $\begin{array}{c}0.25 \pm 0.29^{*} \\
0^{*}\end{array}$ & $\begin{array}{l}0 \\
0\end{array}$ \\
\hline AAME & $\begin{array}{l}250 \\
500\end{array}$ & $\begin{array}{l}8.00 \pm 4.03 \\
3.75 \pm 0.55\end{array}$ & $\begin{array}{l}2.75 \pm 1.28 \\
2.25 \pm 0.73\end{array}$ & $\begin{array}{l}2.50 \pm 0.75 \\
0.75 \pm 0.55\end{array}$ & $\begin{array}{l}2.00 \pm 1.25 \\
2.25 \pm 0.99\end{array}$ & $\begin{array}{l}0.50 \pm 0.58 \\
1.00 \pm 1.16\end{array}$ \\
\hline AAPE & $\begin{array}{l}250 \\
500\end{array}$ & $\begin{array}{l}6.50 \pm 1.73 \\
1.50 \pm 1.11\end{array}$ & $\begin{array}{l}3.25 \pm 1.28 \\
4.50 \pm 2.13\end{array}$ & $\begin{array}{l}0.75 \pm 0.55 \\
1.25 \pm 0.87\end{array}$ & $\begin{array}{l}0.50 \pm 0.33 \\
1.25 \pm 0.55\end{array}$ & $\begin{array}{c}0 \\
1.00 \pm 0.82\end{array}$ \\
\hline VNME & $\begin{array}{l}250 \\
500\end{array}$ & $\begin{array}{l}3.25 \pm 1.72 \\
4.00 \pm 3.27\end{array}$ & $\begin{array}{l}3.25 \pm 1.59 \\
1.25 \pm 0.87^{*}\end{array}$ & $\begin{array}{l}0.25 \pm 0.29^{*} \\
1.00 \pm 0.82^{*}\end{array}$ & $\begin{array}{l}0.50 \pm 0.58^{*} \\
0.25+0.29^{*}\end{array}$ & $0.25 \pm 0.29$ \\
\hline VNPE & $\begin{array}{l}250 \\
500\end{array}$ & $\begin{array}{l}3.50 \pm 2.24 \\
6.25 \pm 4.20\end{array}$ & $\begin{array}{l}1.25 \pm 0.87^{*} \\
2.25 \pm 1.52\end{array}$ & $\begin{array}{l}0.75 \pm 0.87^{\star} \\
1.00 \pm 0.47^{*}\end{array}$ & $\begin{array}{l}0.75 \pm 0.55 \\
0.25 \pm 0.29^{*}\end{array}$ & $\begin{array}{l}0.50 \pm 0.33 \\
0.25 \pm 0.29\end{array}$ \\
\hline
\end{tabular}

Values are presented as mean \pm SEM ( $n=6) ;{ }^{*}: p<0.05 ;{ }^{* *}: p<0.01$ in ANOVA and post hoc Tukey's test 
Table 3: Effects of petroleum ether and methanolic extracts of Manilkara zapota, Abroma augusta, and Vitex negundo in mice on open field test

\begin{tabular}{|c|c|c|c|c|c|c|}
\hline \multirow[t]{2}{*}{ Group } & \multirow{2}{*}{$\begin{array}{c}\text { Dose } \\
\text { (mg/kg) } \\
\text { (p.o) }\end{array}$} & \multicolumn{5}{|c|}{ Mean movements on open field before and after drug administration } \\
\hline & & 0 min & $30 \mathrm{~min}$ & 60 min & 90 min & 120 min \\
\hline Control & $\begin{array}{l}1 \% \text { Tween } \\
80 \text { in water }\end{array}$ & $115.00 \pm 45.56$ & $50.00 \pm 15.61$ & $45.25 \pm 27.11$ & $35.25 \pm 22.84$ & $32.25 \pm 22.71$ \\
\hline Diazepam & 1 & $209.50 \pm 12.71$ & $98.00 \pm 16.91$ & $32.00 \pm 22.33$ & $14.75 \pm 17.03$ & 0 \\
\hline MZPE & $\begin{array}{l}250 \\
500\end{array}$ & $\begin{array}{l}42.50 \pm 23.88^{*} \\
138.25 \pm 66.23\end{array}$ & $\begin{array}{l}34.50 \pm 15.84 \\
33.00 \pm 14.86\end{array}$ & $\begin{array}{l}24.25 \pm 6.35 \\
30.00 \pm 24.50\end{array}$ & $\begin{array}{c}0 \\
10.00 \pm 11.55\end{array}$ & $\begin{array}{c}0 \\
9.00 \pm 8.25\end{array}$ \\
\hline MZME & $\begin{array}{l}250 \\
500\end{array}$ & $\begin{array}{l}148.00 \pm 22.50 \\
232.50 \pm 38.38\end{array}$ & $\begin{array}{c}18.75 \pm 12.68^{*} \\
98.50 \pm 36.48\end{array}$ & $\begin{array}{c}0.25 \pm 0.29^{\star} \\
26.25 \pm 17.50\end{array}$ & $\begin{array}{c}0 \\
12.50 \pm 14.43\end{array}$ & $\begin{array}{c}0 \\
3.75 \pm 4.33\end{array}$ \\
\hline AAME & $\begin{array}{l}250 \\
500\end{array}$ & $\begin{array}{l}132.00 \pm 6.13 \\
54.75 \pm 10.18\end{array}$ & $\begin{array}{c}101.75 \pm 14.27 \\
10.25 \pm 1.09\end{array}$ & $\begin{array}{c}69.25 \pm 12.42 \\
4.00 \pm 2.11\end{array}$ & $\begin{array}{c}26.00 \pm 12.76 \\
0.75 \pm 0.55\end{array}$ & $\begin{array}{c}5.00 \pm 5.77 \\
0\end{array}$ \\
\hline AAPE & $\begin{array}{l}250 \\
500\end{array}$ & $\begin{array}{c}178.75 \pm 16.62 \\
62.75 \pm 31.07\end{array}$ & $\begin{array}{l}100.75 \pm 7.92 \\
36.50 \pm 19.91\end{array}$ & $\begin{array}{l}64.75 \pm 4.72 \\
12.50 \pm 5.93\end{array}$ & $\begin{array}{c}20.50 \pm 9.10 \\
5.00 \pm 5.77\end{array}$ & $\begin{array}{l}3.50 \pm 2.52 \\
3.00 \pm 3.46\end{array}$ \\
\hline VNME & $\begin{array}{l}250 \\
500\end{array}$ & $\begin{array}{l}153.25 \pm 25.75 \\
220.00 \pm 46.13\end{array}$ & $\begin{array}{c}21.25 \pm 10.10 \\
108.00 \pm 44.58\end{array}$ & $\begin{array}{c}1.25 \pm 1.44 \\
29.75 \pm 16.68\end{array}$ & $\begin{array}{c}0.25 \pm 0.29 \\
11.50 \pm 11.79\end{array}$ & $\begin{array}{c}0.25 \pm 0.29 \\
3.50 \pm 4.04\end{array}$ \\
\hline VNPE & $\begin{array}{l}250 \\
500\end{array}$ & $\begin{array}{l}47.50 \pm 25.12^{*} \\
139.25 \pm 70.12\end{array}$ & $\begin{array}{l}33.25 \pm 13.61 \\
38.00 \pm 16.19\end{array}$ & $\begin{array}{c}25.00 \pm .99 \\
31.25 \pm 25.86\end{array}$ & $\begin{array}{c}0.50 \pm 0.58 \\
10.50 \pm 11.34\end{array}$ & $\begin{array}{c}0 \\
14.25 \pm 12.27\end{array}$ \\
\hline
\end{tabular}

Values are presented as mean \pm SEM $(n=6) ;{ }^{*} p<0.05 ;{ }^{* *} p<0.01$ in ANOVA and post hoc Tukey's test

Table 4: Effects of petroleum ether and methanol extracts of Manilkara zapota, Abroma augusta and Vitex negundo on castor oil-induced diarrhea in mice

\begin{tabular}{lccccc}
\hline Treatment & $\begin{array}{c}\text { Dose } \\
(\mathbf{m g} / \mathbf{~ k g})\end{array}$ & $\begin{array}{c}\text { Number of wet } \\
\text { stools }\end{array}$ & $\begin{array}{c}\text { Total number of } \\
\text { stools }\end{array}$ & $\begin{array}{c}\text { Total weight of } \\
\text { stools }\end{array}$ & Protection (\%) \\
\hline Castor oil & $10 \mathrm{ml} / \mathrm{kg}$ & $2.75 \pm 0.87$ & $9.50 \pm 1.80$ & $2.44 \pm 0.35$ & 0 \\
Loperamide & 1 & $3.25 \pm 1.52$ & $8.75 \pm 0.87$ & $0.79 \pm 0.12^{* *}$ & 67.69 \\
MZME & 200 & $4.50 \pm 3.14$ & $8.50 \pm 2.56$ & $0.92 \pm 0.27^{* *}$ & 43.59 \\
& 400 & $5.50 \pm 1.53$ & $9.50 \pm 1.80$ & $1.38 \pm 0.22^{*}$ & 62.26 \\
MZPE & 200 & $4.75 \pm 2.37$ & $9.25 \pm 2.38$ & $0.48 \pm 0.11^{* *}$ & 78.15 \\
& 400 & $2.75 \pm 1.85$ & $7.00 \pm 2.05$ & $0.53 \pm 0.25^{* *}$ & 80.31 \\
AAME & 200 & $2.50 \pm 1.53$ & $8.50 \pm 2.13$ & $1.30 \pm 0.40^{*}$ & 46.67 \\
& 400 & $0.25 \pm 0.23$ & $4.25 \pm 1.97$ & $0.93 \pm 0.59^{*}$ & 62.05 \\
AAPE & 200 & $1.50 \pm 1.00$ & $4.00 \pm 0.82$ & $0.72 \pm 0.28^{* *}$ & 70.67 \\
& 400 & $2.00 \pm 2.31$ & $5.25 \pm 3.54$ & $0.57 \pm 0.31^{* *}$ & 76.82 \\
VNME & 200 & $3.25 \pm 2.33$ & $7.00 \pm 1.25$ & $0.86 \pm 0.22^{* *}$ & 61.74 \\
& 400 & $4.75 \pm 2.47$ & $9.75 \pm 2.56$ & $1.38 \pm 0.22^{*}$ & 38.61 \\
VNPE & 200 & $3.25 \pm 0.73$ & $8.75 \pm 2.37$ & $0.45 \pm 0.10^{* *}$ & 79.98 \\
& 400 & $1.75 \pm 0.73$ & $6.00 \pm 1.41$ & $0.51 \pm 0.24^{* *}$ & 77.18 \\
\hline
\end{tabular}

Values are presented as Mean $\pm \operatorname{SEM}(n=6) ;{ }^{*} p<0.05 ;{ }^{* *} p<0.01$ in unpaired Student's $t$ - test

\section{Antidiarrhoeal activity}

Petroleum ether and methanol extracts showed statistically significant $(p<0.05)$ reduction of diarrheal episode in mice (Table 4). Both extracts administered at the dose of 200 and $400 \mathrm{mg} / \mathrm{kg}$ and showed $78.2 \%$ and $80.3 \%$ protection respectively for MZPE where the MZME showed respectively 43.6 and $62.3 \%$ protection. The frequency of stooling as well as fresh weight also decreased significantly and the result was found significant. For both doses of Abroma augusta and Vitex negundo extracts, the protection was $46.7 \%$ and $62.1 \%$ for AAME and $70.7 \%$ and $76.8 \%$ for AAPE, respectively. The VNPE at two doses showed $80.0 \%$ and $77.2 \%$ protection where methanolic extracts of Vitex negundo showed 61.74 and $38.6 \%$ protection, respectively.

\section{DISCUSSION}

Acetic acid writhing is a model of pain involved mainly in the peripheral mechanism [13]. This model represents pain sensation by triggering localized inflammatory response. Such pain stimulus leads to the release of free arachidonic acid from tissue phospholipids [8]. In our experiment, both MZME and MZPE showed that the plant extracts has good analgesic activity. Acetic acid is supposed to release prostaglandins E2 and F2 $\alpha$ in the peritoneal fluid that excite pain nerve endings [14]. The increase in prostaglandin levels within the peritoneal cavity then enhances inflammatory pain by increasing 
capillary permeability [15]. It has been suggested that these endogenous mediators of pain are sensitive to non-steroidal anti-inflammatory drugs and opioids [16].

Both doses of extracts of $V$. negundo showed significant reduction in writhing induced by the acetic acid after oral administration in a dose dependent manner. At all dose levels, VNME was exhibited higher analgesic activity than VNPE. Our observations support previous results for the analgesic activity of $V$. negundo leaf extract (500 and $1000 \mathrm{mg} / \mathrm{Kg}$ ) using acetic acid induced writhing test in mice for assessing peripheral analgesic effect [17].

The results of Manilkara zapota caused a general inhibition of neuronal activity in the CNS. In the hole cross test the extracts reduced the exploration capacity significantly $(p<0.05)$ which might be considered to be an index of depressors on CNS. A reduction in exploratory behavior with the extract is in conformity with similar actions produced by other CNS depressant drugs [18]. But it is difficult to separate the hole cross test from the open field test by which decreased the locomotor activity was measured. The results obtained demonstrate that the leaf extract has effective CNS depressant potential through diminishing exploratory activity but its action is not promising via locomotor reduction pathway. So it is assumed that the extracts may contain some compounds which decrease the exploratory as well as locomotor activity.

To the best of our knowledge, this is the first report of the Abroma augusta plant extracts on CNS depressant activity. The obtained results showed a decrease in exploratory conduct as well as reduction of spontaneous motility by the methanolic and petroleum ether extracts in a dose-dependent manner. However, the alteration in the general behavior patterns and decreased effects on motor coordination found by the extracts were insignificant compared to vehicle control. However, the general inhibition of neuronal activity in the CNS caused by AAME and AAPE might be considered to be the depressive on CNS.

Both the methanol and pet ether extracts of Vitex negundo exhibited reduction of both exploratory and spontaneous locomotor activity at doses of 250 and $500 \mathrm{mg} / \mathrm{kg}$. The data obtained in our investigation demonstrate that the extracts are not promising for eliciting such activities at threshold level in both hole cross and open field tests. Previously, Gupta et al [11] showed that the methanol extracts of Vitex negundo significant exhibited CNS depressant activity in a dose-dependent manner.

It is well evident that castor oil produces diarrhea due to its most active component recinoleic acid which causes irritation and inflammation of the intestinal mucosa, leading to release of prostaglandins, which results in stimulation of secretion [19]. Therefore, the decreased frequency of stooling and fecal parameters observed with the Manilkara zapota and Abroma augusta extracts are indications of antidiarrhoeal potential. In this study, the 200 and $400 \mathrm{mg} / \mathrm{kg}$ body weight of the extracts of Manilkara zapota showed the best antidiarrhoeal activities. The data presented in our investigation suggest that the antidiarrhoeal activity of Vitex negundo is not promising.

\section{CONCLUSION}

On the basis of the results obtained, there is some justification for the traditional use of the investigated plants in ethnomedical practice. However, further studies are required to identify the exact bioactive compounds responsible for the pharmacological effects observed as well as fully elucidate the underlying mechanisms of action.

\section{ACKNOWLEDGEMENT}

The authors are grateful to the Chairman, Department of Pharmacy as well as the authority of the Southeast University, Banani, Dhaka, Bangladesh for providing laboratory facilities and necessary reagents for the study.

\section{REFERENCES}

1. Ghani A. Medicinal plants of Bangladesh: chemical constituents and uses. 2nd edition ed. 2003: Asiatic Society of Bangladesh; $p 138$.

2. Mohiddin $\mathrm{YBH}$, Chin W, Worth $\mathrm{DH}$. Traditional Medicinal Plants of Brunei Darussalam Part III. Sengkurong. Pharmaceut Biol, 1992; 30(2): 105-108.

3. Prajapati ND, Purohit SS, Sharma AK, Kumar T. A Handbook of Medicinal Plants. Jodhpur: Agrobios, 2003; pp 352-353.

4. Nadkani K. Indian Material Medica. 2nd edn, 2002; pp 1235-1236.

5. Dharmasiri MG, Jayakody JRAC, Galhena G, Liyanage SSP, Ratnasooriya WD. Anti-inflammatory and analgesic activities of mature fresh leaves of Vitex negundo. J Ethnopharmacol, 2003; 87(2): 199-206.

6. Zulfiker AHM, Roy PP, Momin MAM, Khan MS, Bulbul IJ, Ahmed T, Rana MS. Investigation of Antioxidant and Antimicrobial Potential of Chloroform and Petroleum 
Ether Extracts of Selected Medicinal Plants of Bangladesh. Brit J Med Medical Res, 2013; 3(4): 1418-1436.

7. Zimmermann M. Ethical guidelines for investigations of experimental pain in conscious animals. Pain, 1983. 16(2): p. 109-110.

8. Ahmed F, Hossain MH, Rahman AA, Shahid IZ, Antinociceptive and sedative effects of the bark of Cerbera odollam Gaertn. Orient Pharm Exp Med, 2006. 6: 344-348.

9. Zulfiker AHM, Rahman MM, Hossain MK, Hamid K, Mazumder MEH, Rana MS. In vivo analgesic activity of ethanolic extracts of two medicinal plants-Scoparia dulcis L. and Ficus racemosa Linn. Biol Med, 2010, 2(2): $42-48$

10. Takagi $K$, Watanabe $M$, Saito $H$. Studies of the spontaneous movement of animals by the hole cross test; effect of 2-dimethyl-aminoethanol and its acyl esters on the central nervous system. Jap $J$ Pharmacol, 1971; 21(6): 797-810.

11. Gupta M, Mazumder UK, Bhawal SR. CNS activity of Vitex negundo Linn. in mice. Indian J Exp Biol, 1999, 37(2): 143-146.

12. Chitme HR, Chandra M, Kaushik S. Studies on antidiarrhoeal activity of Calotropis gigantea R.Br. in experimental animals. J Pharm Pharm Sci, 2004. $7(1):$ p. $70-5$
13. Davies O, Raventos J, Walpole A. A method for the evaluation of analgesic activity using rats. Brit $J$ Pharmacol Chemother, 1946; 1(4): 255-264.

14. Deraedt R, Jouquey S, Benzoni J, Peterfalvi M. Inhibition of prostaglandin biosynthesis by non-narcotic analgesic drugs. Arch intern pharmacodyn therap, 1976. 224(1): p. 30-42.

15. Zakaria MR, Abd-Aziz S, Ariffin H, Rahman NA,Yee PL, Hassan MA. Comamonas sp. EB172 isolated from digester treating palm oil mill effluent as potential polyhydroxyalkanoate (PHA) producer. Afr J Biotechnol, 2008; 7(22): 4118-4121.

16. Collier HOJ, Dinneen LC, Johnson CA, Schneider C. The abdominal constriction response and its suppression by analgesic drugs in the mouse. Brit $J$ Pharmacol Chemother, 1968; 32(2): 295-310.

17. Telang $R$, Chatterjee $S$, Varshneya $C$. Study on analgesic and anti-inflammatory activities of Vitex negundo Linn. Ind J Pharmacol, 1999; 31(5): 363-366.

18. Dorr S, Midro AT, Farber C, Giannakudis J, Hansmann I. Construction of a detailed physical and transcript map of the candidate region for Russell-Silver syndrome on chromosome 17q23-q24. Genomics, 2001; 71(2): 174-181.

19. Stewart JJ, Gaginella TS, Bass P. Actions of ricinoleic acid and structurally related fatty acids of the gastrointestinal tract. II. Effects on water and electrolyte absorption in vitro. J Pharmacol Exp Ther, 1975; 195: 355-556. 